\title{
TINJAUAN PELAKSANAAN RAPAT ANGGOTA TAHUNAN (RAT) PADA KOPERASI DI KALIMANTAN TIMUR TAHUN 2017
}

\author{
Zulkifli \\ Universitas Widya Gama Mahakam Samarinda \\ zulkifli@uwgm.ac.id \\ Reslianty Rachim \\ Universitas Widya Gama Mahakam Samarinda \\ Reslyanti@gmail.com
}

\begin{abstract}
Abstrak
Salah satu kewajiban pengurus koperasi yaitu menyelenggarakan Rapat Anggota Tahunan minimal 1 tahun sekali. Hal ini merupakan bagian dari cerminan kinerja suatu koperasi dalam satu periode tertentu.

jenis penelitian ini adalah penelitian deskriptif kualitatif atau penelitian dengan tujuan utama Penelitian ini bertujuan untuk menghasilkan dan mendeskripsikan presentasi koperasi yang melaksnakan dan tidak melaksanakan Rapat Anggota Tahunan di Kalimantan Timur dan penyebab koperasi tidak melaksanakan Rapat Anggota Tahunan, sehingga menghasilkan gambaran lengkap mengenai pelaksanaan Rapat Anggota Tahunan di Kalimantan Timur

Pada tahun 2017 di Provinsi Kalimantan Timur pada terdapat 5.401 unit koperasi, diantara seluruh koperasi yang ada tersebut terdapat 2.750 atau sekitar $50.91 \%$ koperasi aktif atau yang masih melaksanakan kegiatan usahanya, sedangkan dari total koperasi aktif tersebut hanya 671 koperasi atau sekitar $24.40 \%$ yang melaksanakan keajibannya menyelenggarakan Rapat Anggota Tahunan sedangkan di bandingkan dengan total koperasi yang ada di Kalimantan Timur hanya $12.42 \%$ saja yang melaksanakan Rapat Anggota Tahunan secara rutin.
\end{abstract}

Kata Kunci : Rapat Anggota Tahunan (RAT)

\section{Pendahuluan}

Menurut Undang-undang nomor 25 Tahun 1992 tentang perkoperasian bahwa koperasi sebagai organisasi ekonomi rakyat bertujuan untuk memajukan kesejahteraan anggota pada khususnya dan masyarakat pada umumnya serta ikut membangun tatanan perekonomian nasional dalam rangka mewujudkan masyarakat yang maju, adil dan makmur berlandaskan Pancasila dan 
Undang-undang Dasar 1945. Dengan memperhatikan kedudukan dan tujuan koperasi tersebut, maka dapat dilihat bahwa peranan koperasi sangatlah penting dalam menumbuhkan dan mengembangkan potensi ekonomi rakyat

Permenkop Nomor 19 tahun 2015 menjelaskan Rapat Anggota untuk meminta pertanggung jawaban Pengurus dan Pengawas yang dilaksanakan paling sedikit 1 (satu) kali dalam setahun, dikenal dengan Rapat Anggota Tahunan;

Rapat anggota koperasi diselenggarakan sedikitnya setahun sekali guna meminta keterangan dan pertanggungjawaban pengurus dan pengawas dalam pelaksanaan tugasnya. Selain itu juga akan dibicarakan kebijakan pengurus dan rencana kerja koperasi untuk tahun buku yang akan datang.

Dengan tertib melaksanakan rapat anggota, diharapkan koperasi dapat mendeteksi masalah koperasi sehingga dapat memberikan solusi lebih cepat, selain itu rapat angoota juga menjadi tempat silaturahmi para anggota dan pengurus dan mengarahkan anggota untuk dapat berperan aktif baik melakukan simpanan maupun bertransaksi sesuai jenis koperasi masing masing.

Menyadari akan pentingnya peranan koperasi maka pertumbuhan dan perkembangannya perlu ditingkatkan. Berbagai upaya serta terobosan yang dilakukan untuk meningkatkan keunggulan koperasi telah dilakukan oleh gerakan koperasi itu sendiri maupun oleh pemerintah mulai tahap offisialisasi, tahap deoffisialisasi hingga sampai pada tahap mandiri (otonom). Perkembangan pembangunan koperasi yang ditunjukkan melalui peningkatan jumlah koperasi dan bertambahnya jumlah anggota yang terdaftar, seyogyanya diikuti dengan perkembangan kualitas baik organisasi maupun usaha koperasi yang dicerminkan dengan meningkatnya kesejahteraan anggota koperasi itu sendiri

Dewasa ini perkembangan kelembagaan koperasi cukup meningkat, namun realita yang kita hadapi ternyata kehidupan koperasi masih dihadapkan pada berbagai macam persoalan antara lain : kemampuan manajemen dalam pengelolaan koperasi masih banyak yang harus dibenahi, masih lemahnya aspek managerial skills dan kewirausahaan dilingkungan koperasi, kurangnya kualifikasi manajer-manajer koperasi, kurang efektifnya program-program pelatihan bagi pengurus koperasi, sistem pengkaderan masih merupakan segi kelemahan 
dalam pengelolaan koperasi, badan pengawas yang berasal dari anggota dinilai kurang professional dalam menjalankan tugas.

Fenomena tersebut seperti lemahnya kemampuan pengawas serta kurangnya partisipasi anggota merupakan permasalahan yang besar pengaruhnya terhadap kualitas perkembangan koperasi baik dari segi organisasi maupun dari segi perkembangan usaha. Dengan kata lain bahwa keberhasilan usaha koperasi selain dipengaruhi oleh alat perlengkapan organisasi koperasi yaitu Rapat Anggota, Pengurus dan Pengawas, juga dipengaruhi oleh partisipasi aktif para anggotanya.

Karena permasalahannya adalah masih banyak koperasi yang belum melaksanakan Rapat Anggota Tahunan. Jika dilihat pelaksanaan Rapat Anggota Tahunan pada koperasi di Kalimantan Timur tahun 2017 sebagai berikut:

Gambar 1.1

Data Koperasi di Kalimantan Timur Tahun 2017

\begin{tabular}{|c|c|c|c|c|c|}
\hline \multirow{3}{*}{ No } & \multirow{3}{*}{ Kota / Kabupaten } & \multicolumn{4}{|c|}{ Tahun 2017} \\
\hline & & \multicolumn{3}{|c|}{ Koperasi (Unit) } & \multirow{2}{*}{$\underset{\text { (Unit }}{\text { RAT }}$} \\
\hline & & JML & Aktif & Tdk Aktif & \\
\hline 1 & Kab. Berau & 361 & 288 & 73 & 80 \\
\hline 2 & Kab. Kutai Barat & 760 & 353 & 407 & 53 \\
\hline 3 & Kab. Kutai Kertanegara & 656 & 498 & 158 & 122 \\
\hline 4 & Kab. Kutai Timur & 1,069 & 583 & 486 & 88 \\
\hline 5 & Kab. Paser & 283 & 222 & 61 & 98 \\
\hline 6 & Kab. Penajam Paser Utara & 242 & 52 & 190 & 23 \\
\hline 7 & Kab. Mahakam Ulu & 120 & 48 & 72 & 1 \\
\hline 8 & Kota Balikpapan & 534 & 427 & 107 & 71 \\
\hline 9 & Kota Bontang & 106 & 66 & 40 & 46 \\
\hline \multirow[t]{3}{*}{10} & Kota Samarinda & 1,235 & 195 & 1,040 & 82 \\
\hline & Binaan Provinsi & 35 & 18 & 17 & 7 \\
\hline & Binaan Nasional & 0 & 0 & 0 & 0 \\
\hline \multicolumn{2}{|r|}{ Jumlah } & 5,401 & 2,750 & 2,651 & 671 \\
\hline
\end{tabular}

sumber data : Diseperindagkop-UKM Kaltim 
Dari data diiatas dapat di jelaskan bahwa pada tahun 2017 jumlah koperasi yang ada diKalimantan Timur 5.401 unit koperasi, diantara seluruh koperasi yang ada tersebut terdapat 2.750 atau sekitar $50.91 \%$ koperasi aktif atau yang masih melaksanakan kegiatan usahanya, sedangkan dari total koperasi aktif tersebut hanya 671 koperasi atau sekitar $24.40 \%$ yang melaksanakan keajibannya menyelenggarakan Rapat Anggota Tahunan sedangkan di bandingkan dengan total koperasi yang ada di Kalimantan Timur hanya $12.42 \%$ saja yang melaksanakan Rapat Anggota Tahunan secara rutin.

Koperasi yang baik tentu akan membutuhkan penerapan fungsi manajemen yang baik. Tidak sedikit kegagalan atau kehancuran sebuah institusi yang disebabkan oleh minimnya pengetahuan mengenai fungsi manajemen yang tepat.

Banyak sekali dampak dari manajemen koperasi yang buruk. Mulai dari sumber daya manusia yang tidak terpelihara, alur koordinasi yang amburadul, sampai pencatatan keuangan yang membuka peluang terjadinya penyimpangan atau setidaknya kesalahan administrasi. Semua faktor di atas sangat bergantung pada seperti apa manajemen yang diterapkan oleh pihak koperasi. maka dari itu fungsi manajemen menjadi sangat penting untuk di analisa dan dipahami lebih jauh mengenai pelaksanaannya pada koperasi. Untuk itu, penelitian ini akan memaparkan pembahasan seputar fungsi manajemen dalam koperasi.

Sehingga peneliti menggali informasi lebih mendalam dengan judul "Penelitian Tinjauan Pelaksanaan Rapat Anggota Tahunan (RAT) Pada Koperasi di Kalimantan Timur tahun $2017^{\prime \prime}$

\subsection{Rumusan Masalah}

Permasalahan yang diangkat dalam penelitian ini berawal dari keinginan peneliti untuk untuk mengetahui bagaimana tingkat Pelaksanaan Rapat Anggota Tahunan (RAT) Pada Koperasi di Kalimantan Timur tahun 2017. Sehingga permasalahan yang diangkat untuk penelitian ini adalah:

1. Bagaimana gambaran koperasi yang dalam melaksanakan Rapat Anggota Tahunan di Kalimantan Timur? 
2. Apakah masalah utama koperasi tidak melaksanaan Rapat Anggota Tahunan ?

3. Bagaimanakah langkah yang telah diambil pemerintah dalam meningkatkan jumlah koperasi yang melaksanakan Rapat Anggota Tahunan

\section{Metode Penelitian}

Mengacu kepada masalah penelitian serta tujuan penelitian yang akan memberikan gambaran mengenai pelaksanaan Rapat Anggota Tahunan pada koperasi di Kalimantan Timur tahun 2017, maka penelitian ini menggunakan jenis penelitian Deskriptif dengan pendekatan kualitatif.

Penelitian kualitatif dalam pandangan Walliman (2006) "Qualitative research does not involve counting and dealing with numbers but is based more on information expressed in words - descriptions, accounts, opinions, feelings, etc" (hlm.129) atau dengan kata lain bahwa penelitian kualitatif tidak melibatkan perhitungan dan angka tetapi lebih didasarkan pada informasi yang disajikan dalam kata-kata - deskripsi, perhitungan, pendapat, perasaan, dll. Selain itu, "qualitative researchproduces narrative or textual descriptions of the phenomena under study" (Vanderstoep \& Johnston, 2009, 7) atau penelitian kualitatif menghasilkan deskripsi narasi atau fenomena tekstual yang diteliti.

Menurut Denzin \& Lincoln (2009) "penelitian kualitatif sebagai sebuah kata yang menyiratkan penekanan pada proses dan makna yang tidak dikaji secara ketat atau belum diukur (jika memang diukur) dari sisi kuantitas, jumlah, intensitas, atau frekuensinya. Para peneliti kualitatif menekankan sifat realita yang terbangun secara sosial, hubungan erat antara peneliti dengan subjek yang diteliti, dan tekanan situasi yang membentuk penyelidikan. Para peneliti semacam ini mementingkan sifat penyelidikan yang sarat nilai. Mereka mencari jawaban atas pertanyaan-pertanyaan yang menyoroti cara munculnya pengalaman sosial sekaligus perolehan maknanya" (hlm.6).

Jadi dalam penelitian ini pendekatan kualitatif adalah penelitian yang menekankan pada penyajian informasi secara deskriptif terhadap realitas Pelaksanaan Rapat Anggota Tahunan (RAT) Pada Koperasi di Kalimantan Timur Tahun 2017 yang diteliti. 


\section{Hasil dan Pembahasan}

A. Permasalahan utama koperasi

Dari hasil penelitian ini setidaknya terdapat dua hal yang menjadi penyebab utama banyak koperasi yang tidak melaksanakan Rapat Anggota Tahunan

\section{Partisipasi anggota}

Dari hasil penelitian ini bahwa masih ada koperasi tidak menjalankan Rapat Anggota Tahunan karena partisipasi anggota untuk menghadiri rapat sangat rendah. menurut peRapat Anggota Tahunanuran menteri nomor 19 tahun 2015 saRapat Anggota Tahunan korum atau sahnya rapat adalah 50 persen +1 dari total aggota koperasi yang aktif. pada initinya Rapat Anggota Tahunan merupakan kewajiban bukan hanya pengurus dan pengawas melainkan seluruh perangkat koperasi.

Partisipasi rendah ini juga disebabkan antara lain oleh anggota maupun pengurus masih ada yang tidak mengerti tugas dan fungsinya. Sehingga tidak ada upaya pengurus maupun anggota untuk berpartisipasi melaksanakan Rapat Anggota Tahunan. Selain itu menyebabkan koperasi sulit untuk melaksanakan Rapat Anggota Tahunan, dampak lain akan partisipasi anggota yang rendah dapat menyebabkan pertumbuhan koperasi yang lambat, mengingat koperasi dibentuk dari anggota sebagai pemilik, oleh anggota menunjuk pelaksana untuk menjalankan koperasi yang disebut sebagai pengurus dan untuk anggota sebagai pengguna jasa koperasi. Sehingga jika peran anggota masih rendah maka dapat dipastikan koperasi tidak dapat berjalan dengan baik

Ditemui juga banyak anggota yang bergabung dikoperasi hanya ingin diberikan pinjaman saja, tanpa ingin menitipkan dananya untuk membesarkan koperasi. Sehingga koperasi harus melakukan pinjaman dengan pihak ketiga untuk memenuhi permohonan anggota. dana dari pihak ketiga ini tentu lebih mahal jika dibanding dengan simpan anggota. sehingga koperasi akan kesulitan bersaing dengan lembaga keuangan lain.

Pemahaman seperti ini dalam bergabung ke koperasi akan dapat menjadi beban koperasi karena anggota hanya berpatisipasi sebagai pengguna saja namun tidak berpartisipasi sebagai pemilik. 
selain itu juga anggota belum memiliki kepercayaan untuk menitipkan dananya di koperasi, justru anggota menitipkan dananya di lembaga keuangan lainnya.

Hal tersebut diatas menggambarkan anggota koperasi cendrung belum merasa memiliki koperasi, seharusnya anggota dan pengurus koperasi harus sadar filosofi berkoperasi sebelum mendirikan atau menjalankan koperasi sehingga dapat menjalankan prinsip koperasi dengan benar. Diantaranyanya menjalankan pendidikan perkoperasian. Sehingga koperasi dapat meningkatkan kualitasnya. Selain itu juga Harus paham bahwa koperasi berdiri dari anggota, oleh anggota, untuk anggota.

Jika keikut sertaan anggota dalam rapat anggota yang diselenggarakan rendah, meskipun mencukupi jumlah dalam pengambilan suatu keputusan, tetap menjadi kendala dalam hal memperoleh banyaknya masukan untuk hal-hal yang dibicarakan pada saat pelaksanaan Rapat Anggota Tahunan tersebut. Hal ini tentunya menghambat banyak ide dan pemikiran yang semestinya bisa didapat dari anggota yang tidak hadir. Terkadang keputusan yang dibuat tidak sesuai dengan kebutuhan anggota.

\section{Kompetensi Pengurus}

Selain hal tersebut diatas yang menjadi kendala, dalam penelitian ini juga ada temuan lain yang dihadapi sehingga koperasi banyak yang tidak melaksanakan Rapat Anggota Tahunan yaitu membuat laporan pertanggungjawaban pengurus dan pengawas. Masih ada koperasi yang telah melaksanakan Rapat Anggota Tahunan namun tidak melaporkan hasil rapat anggotanya keDinas Koperasi setempat karena berbagai alasan diantaranya tidak membuat laporan Rapat Anggota Tahunan. Melainkan hanya mencatat hasil rapat dalam bentuk notulen rapat saja.

Dikoperasi karyawan selain sebagai anggota dan pengurus koperasi sekaligus pegawai pada perusahaan di mana koperasi itu berada. Sehingga mereka juga aktif dalam kegiatan perusahaannya di samping sebagai pengurus koperasi. dengan tingkat pengalaman berkoperasi yang rendah karena mayoritas pengurus merupakan karyawan.

Selain hal tersebut, ada beberapa hal utama kenapa masih banyak koperasi tidak melaksnakan Rapat Anggota Tahunan antara lain : 
a) pengangkatan pengurus koperasi banyak karena ketokohan saja bukan karena kompetensi seorang anggota, sehingga tidak memahamai menjalankan koperasi,

b) kompetensi pengurus, pengawas dan pengelola tidak seusai dengan yang dibidangi

c) Tidak banyak koperasi yang mensyaRapat Anggota Tahunankan Sertifikat kompetensi manajer, kasir dalam pengelolan koperasi.

Tiga hal tersebut yang menjadi penyebab utama koperasi kesulitan dalam menyajikan laporan keuangan dan menjalankan administrasinya dengan benar.

ditegaskan dalam aturan bahwa sekurangnya laporan Rapat Anggota Tahunan memuat tata tertib Rapat Anggota Tahunan koperasi, laporan pertanggung jawaban pengurus yang dibagi dalam 3 (tiga) aspek yaitu: aspek kelembagaan, aspek usaha dan aspek keuangan, serta kejadian penting yang perlu dilaporkan kepada anggota;, laporan pertanggung jawaban badan pengawas 3 aspek yaitu: aspek kelembagaan, aspek usaha dan aspek keuangan, rencana anggaran, pendapatan dan belanja. Jika dilihat standarisasi formal laporan tersebut juga dapat menyebabkan pengurus dan pengawas menjadi kesulitan dalam membuat laporan Rapat Anggota Tahunan.

Selain itu koperasi beranggapan jika usaha koperasi tidak jalan maka koperasi tidak melaksanakan Rapat Anggota Tahunan, harapannya justru sebaliknya dengan adanya Rapat Anggota Tahunan ketika bisnis koperasi tidak jalan maupun ada kendala internal lain yang menyebabkan pengurus tidak melaksanakan Rapat Anggota Tahunan maka harus di rapatkan melalui rapat angggota dan melaporkannya keDinas Koperasi setempat sehingga baik aggota maupun Dinas Koperasi setempat dapat memberikan solusi atau jalan keluar dalam melakukan pengembangan usaha koperasi.

Dalam hasil penelitian ini setidaknya pengurus koperasi harus menguasai dua hal yaitu pengetahuan perkoperasian dan pengetahuan tentang bisnis koperasi. Agar bisnis koperasi bisa terus bertumbuh sesuai prinsip-prinsip koperasi dan dapat melaksanakan aturan Undang Undang No 25 Tahun 1992 tentang perkoperasian dan peRapat Anggota Tahunanuran Menteri Nomor 19 Tahun 2015 tentang penyelenggaraan Rapat Anggota Tahunan dan peRapat Anggota Tahunanuran lainnnya dalam rangka peningkatan daya saing koperasi. 
B. Peran Pembina dalam menangani permasalah penyelenggaraan Rapat Anggota Tahunan Peran dinas sebagai pembina telah melakukan beberapa hal dalam meningkatkan kesadaran pengurus dalam melaksanakan Rapat Anggota Tahunan diantaranya :

1. Mengadakan pendidikan dan pelatihan

Setiap tahun dinas perindagkop Kalimantan Timur maupun kabupaten kota melaksanakan diklat bagi pengurus koperasi dengan tema yang beragam diantaranya : pengembangan usasha, kelembagaan koperasi, pengawasan, dll. Namun Kendala yang di hadapai terkadang pengurus yang datang tidak sesuai dengan tema kegiatan pelatihan, sehingga informasi saat pelaksanaan kegiatan banyak tidak tersampaikan

2. Dinas Koperasi provinsi dan kabupaten kota memiliki pendamping koperasi untuk menangani masalah masalah koperasi namun Kendala nya adalah jumlah koperasi dan jarak antar koperasi tidak sebanding dengan jumlah pendamping koperasi

3. Bidang pengawasan dan kelembagaan koperasi

Setiap dinas setidaknya memiliki bidang yang melakukan pembinaan atau pengawasan pelaksanaan Rapat Anggota Tahunan, dalam aturan bahwa pengawas memberi srat teguran jika koperasi tidak melaksanakan Rapat Anggota Tahunan berturut turut. Kendalanya pegawai Dinas Koperasi yang terkadang mutasi atau promosi ke bidang atau instansi lain. Sehingga petugas baru harus memulai ulang menyesuaikan diri terhadapa aturan aturan yang ada.

\section{KESIMPULAN DAN REKOMENDASI}

\section{A. Kesimpulan}

Pada tahun 2017 di Provinsi Kalimantan Timur pada terdapat 5.401 unit koperasi, diantara seluruh koperasi yang ada tersebut terdapat 2.750 atau sekitar $50.91 \%$ koperasi aktif atau yang masih melaksanakan kegiatan usahanya, sedangkan dari total koperasi aktif tersebut hanya 671 koperasi atau sekitar 24.40\% yang melaksanakan keajibannya menyelenggarakan Rapat Anggota Tahunan sedangkan di bandingkan dengan total koperasi yang ada di Kalimantan Timur hanya $12.42 \%$ saja yang melaksanakan Rapat Anggota Tahunan secara rutin. 
adapun kendala yang dihadapi dan peran pemerintah selaku pembina koperasi adalah sebagai berikut :

1. Masih rendahnya kepercayaan dan partsipasi anggota terhadap koperasi.

2. Kompetensi pengurus yang masih perlu ditingkatkan.

3. Peran Dinas Koperasi selaku pembina sudah cukup baik, namun perlu melakukan penindakan secara bertahap sesuai aturan jika ada koperais tidak melaksanakan rat berturut turut

\section{B. Rekomendasi}

1. Perbanyak masyarakat berkoperasi bukan hanya memperbanyak pendirian koperasi, sehingga koperasi yang berdiri akan sesuai dengan prinsip koperasi di antaranya melaksanakan pendidikan anggota dan pengelolaan koperasi yang baik dengan prinsip Transparansi, Efektifitas dan Efisiensi, Akuntabilitas (Accountability), dan memiliki visi, misi, tujuan yang jelas. sehingga tingkat partisipasi anggota dan kepercayaan anggota dapat meningkat.

2. Dalam menambah anggota koperasi wajib melaksanakan pendidikan anggota. selain itu dalam rangka meningkatkan kompetensi pengurus dan menyelesaikan masalah koperasi, maka, Dinas Koperasi perlu melakukan Identifikasi masalah setiap koperasi, sehingga dalam melaksanakan pelatihan harus sesuai dengan masalah yang dihadapi koperasi. Selain itu peserta yang hadir dalam pelatihan juga harus yang membidangi masalah tersebut. Serta melakukan pemantauan perkembangan hasil pelatihan tersebut. Memantau sejauh mana efektifitas pelaksanaan diklat tersebut dalam mengatasi masalah koperasi.

3. Menindak lanjuti koperasi koperasi yang tidak melaksanakan Rapat Anggota Tahunan berdasarkan aturan sehingga ada menimbulkan efek bagi masyarakat yang ingin mendirikan koperasi dengan niatan lain. 


\section{DAFTAR RUJUKAN}

Buku:

Arfinal Chaniago. Perkoperasian Indonesia. Angkasa. Bandung. 1982

Alston, Margaret., \& Wendy Bowles. 2003. Research for social workers: and introduction to methods (2nd ed.). Canberra: Allen \& Unwin.

Baswir, Revrisond. 2013. Koperasi Indonesia. Yogyakarta: BPFE

Irawan, Prasetya. 2006. Penelitian kualitaif \& kuantitatif untuk ilmu-ilmu sosial. Depok: Departemen Ilmu Administrasi FISIP UI.

Kasmir. (2003). Dasar-Dasar Perbankan. Cetakan Kedua, PT. RajaGrafindo Persada, Jakarta.

Miles, Matthew B., \& A. Michael Huberman. 1994. Qualitative data analyses (second edition). London: SAGE Publications.

Moleong, Lexy J. 2010. Metodologi penelitian kualitatif (Ed. Revisi). Bandung: PT. Remaja Rosdakarya.

Ndraha, Taliziduhu. 2010. Metodologi ilmu pemerintahan. Jakarta: Rineka Cipta.

Neuman, W. Lawrence. 2006. Social Research Methods: Qualitatative and Quantitative Approaches. (4 th ed). USA: Allyn and Bacon.

Raco, J.R. (2010). Metode penelitian kualitatif: jenis, karakteristik dan keunggulannya. Jakarta: PT. Gramedia Widiasarana Indonesia.

Rudianto. (2010). Akuntansi Koperasi Edisi Kedua. Jakarta. Erlangga.

Schensul, Jean J. (2008). "Methodology". Ed. Given, Lisa M. The sage encyclopedia of qualitative research methods volumes 1 \& 2. UK: London, SAGE Publications, Inc. 516521.

Strauss, Anselm L. (1987). Qualitative analysis for social scientists. UK: Cambridge University Press.

Sitio, Arifin. 2001. Koperasi: Teori dan Praktik. Jakarta: Erlangga.

Sugiyono. (2005). Memahami Penelitian Kualitatif, Bandung: Alfabetha

Sugiyono. (2010). Metode penelitian kuantitatif, kualitatif dan R\&D. Bandung: Alfabet 
Vanderstoep, Scott W., \& Dierdre D. Johnston. (2009). Research methods for everyday life: blending qualitative and quantitative approaches. CA: San Fransisco. John Wiley \& Sons, Inc.

Walliman, Nicholas. (2006). Social Research Methods. UK: London SAGE Publications

Jurnal:

Krefting, Laura. (1991). Rigor in qualitative research: the assessment of trustworthiness. The American Journal of Occupational Therapy, 214-222. Vol. 45, No. 3.

Peraturan :

Undang Undang No 25 Tahun 1992 Tentang perkooperasian

Peraturan Menteri Negara Koperasi dan Usaha Kecil dan Menengah Nomor : 10/Per/M.KUKM/XII/2011 